\title{
Media Pop-Up Book pada Topik Perkembangbiakan Tumbuhan dan Hewan Kelas VI Sekolah Dasar
}

\author{
*I Komang Eri Karisma1, I Gede Margunayasa², Pinkan Amita Tri Prasasti ${ }^{3}$ \\ 12 Prodi Pendidikan Guru Sekolah Dasar, Universitas Pendidikan Ganesha, Indonesia \\ ${ }_{3}^{3}$ Prodi Pendidikan Guru Sekolah Dasar, Universitas PGRI Madiun, Indonesia
}

\author{
A R T I C L E I N F O \\ Article history: \\ 1 Maret 2020 Received in \\ revised form \\ 30 Maret 2020 \\ Accepted 11 April 2020 \\ Available online 15 \\ Mei 2020

Kata Kunci:
Youtube,
Pengembangan, pop-up
book, perkembangbiakan
tumbuhan dan hewan
Keywords:
Pengembangan, pop-up
book, perkembangbiakan
tumbuhan dan hewan

\begin{abstract}
A B S T R A K
Penelitian ini bertujuan untuk mengembangkan media pop-up book pada topik perkembangbiakan tumbuhan dan hewan kelas VI sekolah dasar. Penelitian ini merupakan penelitian pengembangan yang dilaksanakan dengan menggunakan model ADDIE (Analyse, Design, Development, Implementation, Evaluation) dengan tahapan-tahapan yaitu: (1) analisis, (2) desain, (3) pengembangan, (4) implementasi, dan (5) evaluasi. Namun, karena keterbatasan waktu, tenaga, dan sumber daya, maka penelitian ini hanya dilaksanakan sampai tahap pengembangan. Tahap implementasi dan evaluasi tidak dilaksanakan dalam penelitian ini. Subjek penelitian ini adalah media pop-up book pada topik perkembangbiakan tumbuhan dan hewan. Metode pengumpulan data yang digunakan adalah metode kuesioner dengan memberikan lembar penilaian kepada 2 orang guru dan 2 orang dosen sebagai ahli. Instrumen yang digunakan untuk mengukur tingkat validitas media pop-up book adalah rating scale berupa lembar penilaian media pop-up book oleh ahli. Data yang diperoleh kemudian dianalisis dengan menggunakan rumus mean untuk mengetahui rata-
\end{abstract} rata skor validitas media pop-up book. Nilai rata-rata validitas media pop-up book yang diperoleh adalah 4.85 dengan kualifikasi sangat baik. Berdasarkan analisis tersebut maka media pop-up book yang dikembangkan pada topik perkembangbiakan tumbuhan dan hewan dinyatakan valid dan dapat digunakan dalam pembelajaran di kelas VI sekolah dasar.

\begin{abstract}
A B S T R A C T
The aim of this research was to develop pop-up books media on the topic of plant and animal breeding on sixth grade elementary students. This research was a development research which was carried out by using the ADDIE model (Analyze, Design, Development, Implementation, Evaluation) in five steps, namely: (1) analysis, (2) design, (3) development, (4) implementation, and (5) evaluation. However, this research was only carried out until development step because the time, resources and financial limitation. The implementation and evaluation were not carried out in this research. The subject of this research was the pop-up books media on the topic of plant and animal breeding. Meanwhile the object was the validity of pop-up book media. The data collection method used was a questionnaire method by providing assessment sheet for 2 teachers and 2 lecturers as the experts. The instrument used to measure the level of validity of media pop-up book was rating scale of media pop-up books assessment sheet by the experts. The data obtained then analyzed by using a mean formula to know the average score validity of pop-up book media. The average score was 4.85 in the level of very good qualification. Based on this analysis, the pop-up book media developed on the topic of plant and animal breeding was valid and could be used in learning on six grade elementary students.
\end{abstract}

\section{Pendahuluan}

Pembelajaran inovatif merupakan pembelajaran yang lebih mengarah pada pembelajaran yang berpusat pada peserta didik (Muhali, 2019). Guru bertugas merancang, menyusun, serta mengkondisikan 
agar peserta didik mampu belajar dengan sendirinya. Pembelajaran dirancang agar menyenangkan sehingga peserta didik dapat memusatkan perhatiannya secara penuh untuk belajar (Muhali, 2019). Untuk menciptakan pembelajaran yang inovatif diperlukan inovasi dalam pembelajaran. Inovasi dalam pembelajaran pada dasarnya merupakan suatu perubahan ataupun pemikiran cemerlang yang bercirikan hal baru ataupun pemikiran cemerlang tertentu yang berupa produk atau hasil olah pikir dan olah teknologi yang diterapkan dengan tujuan untuk memecahkan persoalan pendidikan dan memperbaiki keadaan pendidikan yang terjadi dalam masyarakat sehingga pembelajaran bisa berjalan dengan efektif (Kusnandi, 2017).

Untuk menciptakan pembelajaran yang efektif diperlukan interaksi dan komunikasi yang intesif antara guru dan siswa. Namun, ketika dalam pembelajaran guru masih mendominasi tanpa memberikan siswa kesempatan untuk terlibat aktif maka pembelajaran akan menjadi kurang efektif (Inah, 2015). Pembelajaran seharusnya mampu melibatkan partisipasi aktif dan memungkinkan peserta didik untuk aktif manemukan, memproses, dan mengkonstruksi ilmu pengetahuannya sendiri (Rizal, 2018). Disamping itu, menurut Bruner untuk belajar konsep-konsep dan prinsip-prinsip siswa harus terlibat aktif dalam proses pembelajaran (Kumara, 2004). Untuk dapat menciptakan pembelajaran yang melibatkan partisipasi aktif siswa maka terlebih dahulu guru harus mampu mengidentifikasi karakteristik siswanya. Mengidentifikasi perilaku awal dan karakteristik siswa dalam pembelajaran dipandang perlu untuk dilakukan agar mampu mengetahui kualitas perorangan sehingga nantinya dapat dijadikan pentunjuk dalam menentukan strategi pembelajaran (Lubis, 2018).

Menentukan strategi pembelajaran untuk siswa sekolah dasar harus terlebih dahulu memahami karakteristik yang mereka miliki. Menurut teori perkembangan kognitif Piaget, anak usia sekolah dasar berada pada tahap oprasional konkret yang pada saat belajar memerlukan objek yang bersifat konkret. Mereka akan kesulitan apabila tanpa bantuan benda-benda yang mampu merepresentasikan hal yang dimaksud (Ibda, 2015). Oleh karena itu, penggunaan media dalam proses pembelajaran di sekolah dasar sangat penting untuk dilakukan.

Secara harfiah media berasal dari bahasa latin yaitu medium yang dapat diartikan sebagai perantara (Mustika, 2015). Media dapat diartikan sebagai suatu alat atau sarana yang digunakan sebagai perantara untuk menyampaikan sesuatu (Karo-Karo \& Rohani, 2018). Sementara itu, media merupakan suatu wadah dari pesan yang ingin disampaikan oleh sumber pesan yang kepada penerima pesan atau sasaran yang akan dituju (Maimunah, 2016). Dalam pembelajaran media memiliki fungsi yang sangat penting, yaitu untuk menarik dan menumbuhkan minat belajar siswa, serta memudahkan guru menyampaikan materi pembelajaran (Dewanti, dkk., 2018).

Namun, sekarang ini penggunaan serta pengembangan media dalam pembelajaran belum dilakukan secara optimal, guru hanya menggunakan buku dalam proses pembelajaran, padahal buku yang digunakan masih memiliki banyak kekurangan serta penyajian materi kurang menarik (Oktaviarini, 2017). Berdasarkan hasil studi dokumen yang dilakukan pada buku siswa kelas VI ditemukan bahwa materi yang tersedia dalam buku siswa khususnya materi muatan IPA sangat terbatas. Hal ini juga didukung dengan hasil kuesioner yang disebar kepada guru kelas VI di SD Gugus V Kecamatan Sukasada tahun pelajaran 2019/2020 pada tanggal 7-13 November 2019 menunjukkan bahwa: (1) 54\% guru menyatakan bahwa materi muatan IPA yang ada pada buku siswa masih dangkal karena penjelasan yang terdapat pada buku masih sangat sedikit hanya beberapa kalimat saja, disamping itu, beberapa penjelasan materi yang ada pada buku belum dilengkapi dengan gambar (2) 67\% guru menyatakan bahwa materi muatan IPA yang terdapat pada buku siswa sangat perlu untuk dikembangkan. Keterbatasan materi muatan IPA yang terdapat pada buku siswa berdampak pada menurunnya pemahaman Sains siswa. Hal ini didukung oleh hasil PISA pada tahun 2018 yang dirilis OECD yang menyatakan bahwa kemampuan Sains siswa di Indonesia mendapat skor 389 berada di bawah rata-rata skor OECD yaitu 489 (Indriani, 2019).

Untuk menambah wawasan siswa terhadap IPA maka upaya yang dapat dilakukan adalah mengembangkan materi pembelajaran dan mengemasnya ke dalam media pop-up book. Hal ini didukung dengan hasil penyebaran kuesioner di SD Gugus V Kecamatan Sukasada tahun pelajaran 2019/2020 yang menyatakan bahwa 78\% guru menyatakan sangat setuju apabila materi muatan IPA dikembangkan dalam bentuk media pop-up book, dan $22 \%$ guru menyatakan setuju jika materi IPA yang terdapat pada buku siswa dikembangkan dalam bentuk pop-up book. Sementara itu, 72\% siswa menyatakan bahwa materi muatan IPA yang terdapat pada buku siswa sangat perlu dikembangkan dalam bentuk pop-up book.

Media pop-up book merupakan sebuah buku yang bisa menampilkan halaman yang di dalamnya terdapat lipatan gambar yang membentuk tiga dimensi dan dapat digerakkan sehingga minat pembaca untuk mebaca menjadi lebih meningkat (Sholikhah, 2017). Media pop-up book dipandang dapat memberikan kesan yang dapat menarik perhatian siswa dan dipandang dapat menumbuhkan semangat belajar peserta didik. Penggunaan media pop-up book akan membuat peserta didik lebih fokus mengamati 
materi yang tersedia pada pop-up book (Wati \& Zuhdi, 2017). Pop-up book merupakan buku yang dapat memperlihatkan bentuk tiga dimensi ketika halamannya dibuka serta memiliki gerak yang dapat dikreasikan dengan menggunakan kertas sebagai bahan lipatan, gulungan, bentuk, ataupun roda (Oktaviarini, 2017). Beberapa keunggulan media pop-up book dibandingkan dengan media lainnya adalah (1) dapat menampilkan gambar menjadi lebih menarik, (2) dapat digunakan sebagai bahan ajar yang dalam pengguaannya bisa dilakukan secara individu maupun kelompok, (3) penggunaanya sangat praktis dan dapat meningkatkan semangat belajar siswa, (4) memiliki tampilan yang unik dan hal ini menjadi keunggulan media pop-up book dibandingkan media lainnya, (5) memiliki dimensi gambar yang timbul saat halaman dibuka (Masturah, dkk., 2018).

Pop-up book efektif digunakan sebagai media pembelajaran hal ini didukung oleh penelitian Sholikhah (2017) yang menyatakan bahwa hasil validasi dengan tingkat kevalidan mencapai 4,5 dengan tingkat respon siswa yang mencapai 96,9\% dan keseluruhan indikator guru melampaui 65\%. Penelitian Masturah, dkk., (2018) yang memperoleh hasil review ahli mata pelajaran sebesar 95,8\%, ahli desain pembelajaran mencapai $88 \%$, dan ahli media pembelajaran sebesar 98,5 . Berdasarkan uji validitas media dinyatakan valid dengan kategori sangat baik. Serta penelitian yang dilakukan oleh Baiduri dkk (2019) yang menunjukkan bahwa hasil validasi media pop-up book sangat valid yang berarti layak digunakan sebagai media pembelajaran. Tujuan penelitian ini adalah untuk mengembangkan media pop-up book pada topik perkembangbiakan tumbuhan dan hewan di kelas VI sekolah dasar tahun pelajaran 2019/2020 yang sudah teruji validitasnya.

\section{Metode}

Penelitian ini merupakan penelitian pengembangan media pop-up book pada topik perkembangbiakan tumbuhan dan hewan kelas VI sekolah dasar. Pada penelitian ini menggunakan model ADDIE. Model ini terdiri dari 5 tahapan yaitu: (1) analisis (analyse), (2) perancangan (design), (3) pengembangan (development), (4) implementsi (implementation), dan (5) evaluasi (evaluation) (Tegeh \& Jampel, 2017). Namun, pada penelitian ini tahap implementasi dan evaluasi tidak dilaksanakan. 1) Tahap analisis dilakukan dengan melakukan analisis kebutuhan, analisis kurikulum, analisis karakteristik siswa, dan analisis media yang baik. Analisis kurikulum dilakukan dengan menganalisis Kompetensi Inti (KI), Kompetensi Dasar (KD), dan indikator pencapaian kompetensi yang terdapat pada buku siswa sehingga nantinya dapat digunakan sebagai acuan dalam mengembangkan media pop-up book. Analisis kebutuhan dilakukan untuk mengetahui kebutuhan yang diperlukan oleh guru dan siswa dalam proses pembelajaran khususnya pada topik perkembangbiakan tumbuhan dan hewan. Analisis kebutuhan ini dilakukan dengan cara memberikan kuesioner kepada guru dan siswa. Analisis karakteristik siswa meliputi melakukan analisis terhadap peserta didik yang akan menggunakan media yang dikembangkan. Analisis media yang baik digunakan untuk mengetahui karakteristik media yang baik. 2) Tahap desain dilakukan perancangan media pembelajaran pop-up book yang dimulai dari menentukan materi yang akan dikembangkan dalam media pop-up book, membuat rancangan pop-up book menggunakan bantuan software Photoshop CS5, kemudian dikonsultasikan dengan dosen pembimbing untuk mendapatkan masukan atau saran agar bisa dilakukan perbaikan. 3) Tahap pengembangan dilakukan pengembangan media pop-up book yang telah dikonsultasikan dengan dosen pembimbing. Setelah dilakukan pengembangan selanjutnya dilakukan penilaian oleh 2 orang dosen dan 2 orang guru.

Setelah media pop-up book selesai dikembangkan selanjutnya dilaksanakan uji coba produk untuk mengetahui validias media. Desain uji coba dalam penelitian ini melalui tahapan review dari ahli untuk mengetahui validitas media pop-up book yang telah dikembangkan. Setelah di review oleh ahli, data hasil review kemuadian dianalisis berdasarkan data yang diperoleh. Subjek dalam penelitian ini adalah media pop-up book pada topik perkembangbiakan tumbuhan dan hewan di kelas VI sekolah dasar. Sedangkan objek dalam penelitian ini adalah validitas media pop-up book yang dikembangkan. Data yang diperoleh dalam penelitian ini dikelompokkan menjadi dua yaitu data kualitatif dan data kuantitatif. Data kualitatif diperoleh berdasarkan masukan, saran, kritik, yang diperoleh dari review yang dilakukan oleh ahli media pembelajaran. Metode yang digunakan dalam pengumpulan data dalam penelitian ini adalah metode kuesioner. Instrumen yang digunakan adalah rating scale yang berupa lembar penilaian media pop-up book. Instrumen lembar validitas media mencangkup 6 aspek yaitu aspek sampul, format, isi, bahasa, praktis, dan efektivitas. Keenam aspek tersebut dibuat dalam bentuk intrumen berdasarkan kriteria masing-masing aspek yaitu: (1) kriteria aspek sampul meliputi identitas dan kemenarikan sampul (2) aspek format meliputi warna, tulisan, huruf, dan tata letak; (3) kriteria aspek isi meliputi kecocokan materi dengan indikator, kemampuan media menjelaskan materi, kelengkapan materi, dan daya tarik materi pada media; (4) kriteria aspek bahasa meliputi penggunaan bahasa, kebakuan bahasa, dan 
keefektifan kalimat; (5) kriteria aspek praktis berkaitan dengan penggunaan media; dan (6) kriteria aspek efektif juga berkaitan dengan penggunaan media (Monika, 2014).

Sebelum diuji dalam penelitian, instrumen yang digunakan harus valid. Untuk menguji validitas isi instrumen perlu dilakukan uji judges (pakar) dalam bidangnya. Uji validitas isi dalam penelitian ini menggunakan rumus Gregory. Data yang diperoleh ahli (judges) dikonversikan ke dalam tabulasi silang 2 $\times 2$. Seperti pada Tabel 1 .

Tabel 1. Tabulasi Silang

\begin{tabular}{cccc}
\hline \multirow{2}{*}{ Judges } & \multicolumn{3}{c}{ Judges I } \\
\cline { 2 - 4 } & Penilaian Judges & Kurang Relevan & Sangat Relevan \\
\hline \multirow{2}{*}{ Judges II } & Kurang Relevan & $\mathrm{A}(--)$ & $\mathrm{B}(-+)$ \\
\cline { 2 - 4 } & Sangat Relevan & $\mathrm{C}(+-)$ & $\mathrm{D}(++)$ \\
\hline
\end{tabular}

Hasil dari Tabel 1 dapat dicari validitas isi dengan menggunakan rumus Gregory:

$$
V=\frac{D}{A+B+C+D}(\text { Candiasa, 2011). }
$$

Keterangan:

V: validitas isi

A: jumlah skor yang diperoleh jika kedua judges menyatakan tidak relevan

B: jumlah skor yang diperoleh jika judges I menyatakan tidak relevan tetapi pakar II menyatakan relevan

C: jumlah skor yang diperoleh jika judges I menyatakan relevan tetapi pakar II menyatakan tidak relevan.

D: jumlah skor yang diperoleh jika kedua judges menyatakan relevan

Berdasarkan uji validitas isi menunjukkan koefisien validitas isi instrumen penilaian media pop-up book $=1.00$. Hasil uji validitas isi menunjukkan bahwa validitas isi instrumen penilaian media pop-up book berada pada kategori validitas sangat tinggi.

Metode dan teknik analisis data yang digunakan dalam penelitian pengembangan ini adalah metode analisis deskriptif kualitatif dan analisis deskriptif kuantitatif. Metode analisis deskriptif kualitatif adalah cara pengolahan data dalam bentuk kalimat atau kata-kata atau kategori mengenai suatu objek (Agung, 2014). Metode analisis deskriptif kualitatif digunakan untuk mengolah data berupa masukan, tanggapan, kritik, dan saran dari hasil review oleh para ahli terhadap media yang dikembangkan melalui lembar penilaian media pop-up book. Metode analisis deskriptif kuantitatif digunakan untuk memperoleh ratarata skor dari masing-masing ahli terkait media yang dikembangkan. Metode ini digunakan untuk menganalisis data berupa skor yang diperoleh melalui lembar penilaian dari para ahli. Rata-rata skor yang diperoleh kemudian dikonversikan dengan menggunakan pedoman konversi skala lima seperti tabel 2 . Dalam penelitian ini yang digunakan sebagai indikator keberhasilan adalah rata-rata skor validasi media pop-up book minimal pada kategori baik dengan rentang $3.01<\mathrm{x} \leq 4.01$.

Tabel 2. Penilaian Skala Lima

\begin{tabular}{cc}
\hline Rentangan Skor & Klasifikasi Predikat \\
$4,01<\mathrm{X} \leq 5,01$ & Sangat Baik \\
$3,34<\mathrm{X} \leq 4,01$ & Baik \\
$2,66<\mathrm{X} \leq 3,34$ & Cukup \\
$1,99<\mathrm{X} \leq 2,66$ & Tidak Baik \\
$0,99<\mathrm{X} \leq 1,99$ & Sangat Tidak Baik \\
\hline
\end{tabular}

Sumber : (Koyan, 2012)

\section{Hasil dan pembahasan}

Penelitian ini dilaksanakan untuk mengembangkan media pop-up book pada topik perkembangbiakan tumbuhan dan hewan kelas VI di Gugus V Kecamatan Sukasada tahun pelajaran 2019/2020. Hasil penelitian ini adalah media pop-up book yang sudah valid. Hasil tersebut diperoleh melalui tahap analisis, perancangan, pengembangan, serta validasi produk oleh dosen dan guru.

Tahap analisis terdiri dari analisis kebutuhan, analisis kurikulum, analisis karakteristik siswa, serta analisis kriteria media yang baik. Analisis kebutuhan dilakukan dengan menyebarkan koesioner kepada guru dan siswa kelas VI di SD Gugus V Kecamatan Sukasada yang menyatakan bahwa 78\% guru 
menyatakan sangat setuju, dan 22\% guru menyatakan setuju apabila materi muatan IPA dikembangkan ke dalam media pop-up book. Sementara itu, 72\% siswa menyatakan bahwa materi muatan IPA yang terdapat pada buku sangat perlu dikembangkan ke dalam bentuk pop-up book. Analisis kurikulum dilakukan dengan melakukan analisis Kompetensi Inti (KI), Kompetensi Dasar (KD), serta indikator pencapaian kompetensi yang digunakan sebagai acuan dalam mengembangkan media. Analisis karakteristik siswa digunakan untuk mengetahui karakteristik siswa yang akan menggunakan media. Analisis media yang baik digunakan untuk menganalisis kriteria media yang baik untuk SD. Adapun media pop-up book yang dikembangkan mengacu pada 6 aspek yang meliputi: (1) kriteria aspek sampul meliputi identitas dan kemenarikan sampul (2) aspek format meliputi warna, tulisan, huruf, dan tata letak; (3) kriteria aspek isi meliputi kecocokan materi dengan indikator, kemampuan media menjelaskan materi, kelengkapan materi, dan daya tarik materi pada media; (4) kriteria aspek bahasa meliputi penggunaan bahasa, kebakuan bahasa, dan keefektifan kalimat; (5) kriteria aspek praktis berkaitan dengan penggunaan media; dan (6) kriteria aspek efektif juga berkaitan dengan penggunaan media (Monika, 2014).

Pada tahap perancangan dilakukan perancangan media yang akan dikembangkan. Rancangan media menggunakan aplikasi Photoshop CS5. Rancangan media kemudian dikonsultasikan dengan dosen pembimbing untuk mendpatkan masukan dan saran. Setelah disetujui oleh dosen pembimbing kemudian dilanjutkan ke tahap pengembangan.

Tahap pengembangan dilakukan dengan mulai mengembangkan media sesuai dengan rancangan yang telah disetujui oleh dosen pembimbing. Media dikembangkan dengan sampul yang menarik, dilengkapi petunjuk penggunaan media, KD dan indikator pencapaian kompetensi, serta terdapat latihan soal pada halaman terakhir. Setelah media selesai dikembangkan tahap selanjutnya adalah melakukan uji coba media untuk mengetahui validitas media yang dikembangkan.

Hasil validitas media pop-up book pada topik perkembangbiakan tumbuhan dan hewan kelas VI Sekolah Dasar yang diperoleh disajikan pada tabel 3.

Tabel 3. Hasil Validasi Media Pop-Up Book

\begin{tabular}{|c|c|c|c|c|c|}
\hline \multirow[t]{2}{*}{ No } & \multirow[t]{2}{*}{ Butir Penilaian } & \multicolumn{4}{|c|}{ Skor } \\
\hline & & Ahli (1) & Ahli (2) & Ahli (3) & $\begin{array}{c}\text { Ahli } \\
(4)\end{array}$ \\
\hline 1 & Identitas pada sampul media pop-up book. & 5 & 5 & 4 & 5 \\
\hline 2 & Kemenarikan sampul pada media pop-up book. & 5 & 5 & 5 & 5 \\
\hline 3 & $\begin{array}{l}\text { Keserasian warna, tulisan, dan gambar pada media } \\
\text { pop-up book. }\end{array}$ & 5 & 5 & 5 & 5 \\
\hline 4 & Keserasian penggunaan dan ukuran huruf. & 4 & 5 & 4 & 5 \\
\hline 5 & Kesesuaian tata letak/layout media pop-up book. & 4 & 5 & 5 & 5 \\
\hline 6 & $\begin{array}{c}\text { Kesesuaian materi pada media pop-up book dengan } \\
\text { indikator pembelajaran. }\end{array}$ & 5 & 5 & 5 & 5 \\
\hline 7 & $\begin{array}{l}\text { Kelengkapan materi/informasi yang dimuat dalam } \\
\text { media pop-up book. }\end{array}$ & 5 & 5 & 5 & 5 \\
\hline 8 & $\begin{array}{l}\text { Isi media pop-up book dapat menimbulkan rasa ingin } \\
\text { tahu siswa. }\end{array}$ & 5 & 5 & 5 & 5 \\
\hline 9 & Kemudahan memahami bahasa yang digunakan. & 5 & 5 & 4 & 5 \\
\hline 10 & $\begin{array}{c}\text { Kesesuaian bahasa yang digunakan dengan kaidah } \\
\text { Bahasa Indonesia. }\end{array}$ & 5 & 5 & 4 & 5 \\
\hline 11 & Keefektifan struktur kalimat yang digunakan. & 5 & 5 & 4 & 5 \\
\hline 12 & Kemudahan penggunaan media pop-up book. & 5 & 5 & 5 & 5 \\
\hline 13 & $\begin{array}{c}\text { Media pop-up book membantu guru menjelaskan } \\
\text { materi. }\end{array}$ & 5 & 5 & 5 & 4 \\
\hline & Rata-rata Ahli & 4.85 & 5.00 & 4.62 & 4.92 \\
\hline & Rata-rata Keseluruhan & & 4.8 & & \\
\hline
\end{tabular}


Berdasarkan hasil analisis data berupa rata-rata skor validitas media pop-up book oleh 4 orang ahli pada topik perkembangbiakan tumbuhan dan hewan kelas VI sekolah dasar, skor rata-rata ahli 1 sebesar 4.85, skor rata-rata ahli 2 sebesar 5.00, skor rata-rata ahli 3 sebesar 4.62, dan skor rata-rata ahli 4 sebesar 4.92. Sedangkan validitas media pop-up book memperoleh skor rata-rata keseluruhan sebesar 4.85. Berdasarkan hasil kualifikasi skala lima maka media pop-up book berkualifikasi "sangat baik".

Berpijak pada deskripsi hasil penelitian yang telah dijelaskan sebelumnya, pengembangan media pop-up book ini menggunakan model ADDIE dengan tahapan analyze, design, development, implementation, dan evaluation. Namun dalam penelitian ini hanya terbatas sampai tahap development (pengembangan) karena keterbatasan waktu, tenaga, dan sumber daya. Pemilihan model ini didasari atas pertimbangan bahwa model ADDIE dikembangkan secara sistematis dan berpijak pada landasan teoritis desain pembelajaran.

Tahap analyze (analisis) yang dilakukan terdiri dari tahapan analisis kurikulum, analisis kebutuhan, analisis karakteristik siswa, dan analisis media yang baik. (1) tahap analisis kurikulum dilakukan dengan menganalisis Kompetensi Inti (KI), Kompetensi Dasar (KD), dan indikator pencapaian kompetensi yang terdapat pada buku siswa sehingga nantinya dapat digunakan sebagai acuan dalam mengembangkan media pop-up book (2) analisis kebutuhan dilakukan untuk mengetahui kebutuhan yang diperlukan oleh guru dan siswa dalam proses pembelajaran khususnya pada topik perkembangbiakan tumbuhan dan hewan. Analisis kebutuhan ini dilakukan dengan cara memberikan kuesioner kepada guru dan siswa (3) analisis karakteristik siswa meliputi melakukan analisis terhadap peserta didik yang akan menggunakan media yang dikembangkan (4) analisis media yang baik digunakan untuk mengetahui karakteristik media yang baik.

Tahap design (desain) dilakukan perancangan media pembelajaran pop-up book yang dimulai dari menentukan materi yang akan dikembangkan dalam media pop-up book, membuat rancangan pop-up book menggunakan bantuan software Photoshop CS5, kemudian dikonsultasikan dengan dosen pembimbing untuk mendapatkan masukan atau saran agar bisa dilakukan perbaikan.

Tahap development (pengembangan) pada tahap ini dilakukan pengembangan media pop-up book yang telah dikonsultasikan dengan dosen pembimbing. Setelah dilakukan pengembangan selanjutnya dilakukan penilaian oleh 2 orang dosen dan 2 orang guru. Data hasil penilaian dan guru kemudian dianalisis untuk mengetahui kelayakannya.

Tampilan media pop-up book perkembangiakan tumbuhan dan hewan kelas VI sekolah dasar yang dikembangkan dapat dilihat pada Gambar 1.

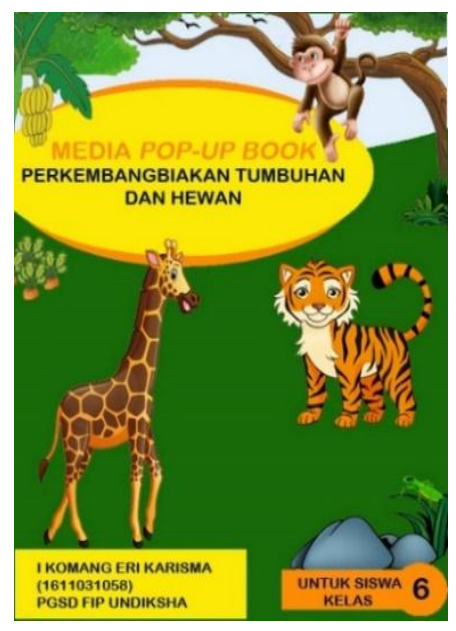

(a) Cover Depan

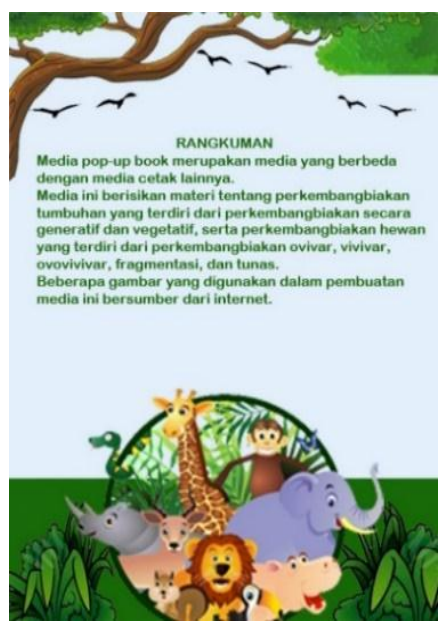

(b) Cover Belakang 

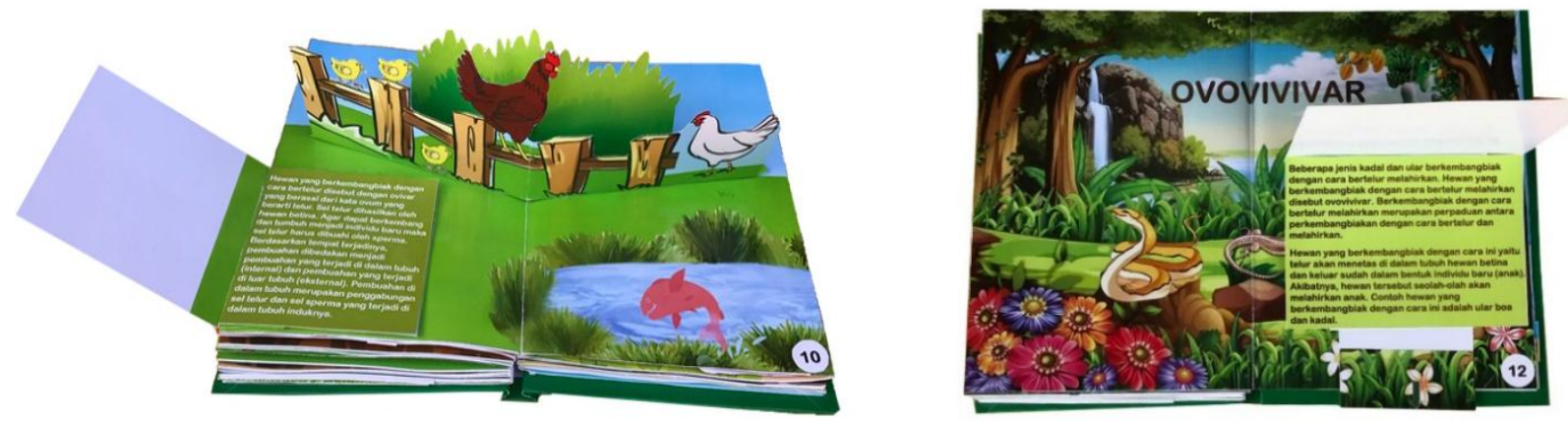

(c) Bagian Isi

\section{Gambar 01 \\ Cover Depan, Cover Belakang, dan Bagian Isi}

Berdasarkan pada hasil analisis validitas media pop-up book yang dilakukan diperoleh hasil ratarata skor validasi dengan skor 4.85. Setelah dikonversi ke tabel skala lima menunjukkan bahwa media pop-up book yang dikembangkan berkualifikasi "sangat baik".

Berdasakan kualifikasi yang diperoleh, media pop-up book yang dikembangkan berada pada kualifikasi "sangat baik". Hal ini menunjukkan bahwa media pop-up book pada topik perkembangbiakan tumbuhan dan hewan layak digunakan sebagai media pembelajaran bagi siswa sekolah dasar. Hal ini sejalan dengan teori perkembangan kognitif Piaget yang menyatakan bahwa anak usia sekolah dasar memerlukan objek yang bersifat konkret dalam pembelajaran (Ibda, 2015). Hal ini dapat difasilitasi dengan menggunakan media pop-up book yang telah dikembangkan. Pop-up book merupakan media pembelajaran tiga dimensi berbentuk buku yang memuat gambar timbul ketika dibuka (Ambarsari \& Hartono, 2017).

Media pop-up book memiliki keunggulan dibandingkan media cetak lainnya. Adapun keunggulan media pop-up book dibandingkan dengan media cetak lainnya yaitu: (1) pop-up book dibuat menggunakan kertas yang tebal sehigga tidak mudah rusak, (2) setiap bagian pop-up book berisi halaman dengan gambar yang menarik, (3) membuat siswa lebih aktif dan antusias dalam belajar, (4) pop-up book bisa digunakan secara individu ataupun dalam kelompok (Anggraini, dkk., 2019). Sedangkan, ditinjau dari aspek sajian media pop-up book dapat dibuka dan ditutup tanpa merusak atau merobek lembaran kertas yang lain, kertas lembaran pop-up book tidak berpotongan sehingga tidak ada halangan saat membuka atau menutup setiap halaman pada media, pop-up book rapi saat tertutup, pop-up book memiliki unsur bentuk, warna, dan tekstur yang menarik, dan pop-up book tidak mudah rusak (Fadillah \& Lestari, 2016). Disamping itu, kelebihan media pop-up book ini, yaitu: (1) membantu guru dalam menyampaikan materi pada topik perkembangbiakan tumbuhan dan hewan; (2) membuat pembelajaran menjadi lebih menarik dan dapat mengefisienkan waktu dan tenaga; (3) meningkatkan minat dan motivasi siswa untuk belajar, karena dengan penggunaan media ini siswa mendapatkan pengalaman belajar baru sehingga berdampak kemampuannya, (4) mampu meningkatkan keterlibatan siswa saat proses pembelajaran, sehingga pengetahuan yang didapat lebih dipahamai dan tahan lama.

Penelitian pengembangan ini menghasilkan media pop-up book pada topik perkembangbiakan tumbuhan dan hewan. Media pop-up book pada topik perkembangbiakan tumbuhan dan hewan yang dikembangkan berbeda dengan media pop-up book lainnya karena belum ada yang mengembangkan media yang sejenis pada materi perkembangbiakan tumbuhan dan hewan di kelas VI Sekolah dasar. Disamping itu, media dikembangkan dengan gambar yang menarik serta dibuat menggunakan kertas yang tebal. Media ini dikembangkan berdasarkan hasil analisis kebutuhan di lapangan. Sehingga media ini mampu menjadi solusi dalam mengatasi permasalahan yang ada. Penggunaan media pop-up book sejalan dengan teori konstruktivisme yang lebih menitikberatkan pada dibangunnya pengetahuan secara langsung oleh siswa yang diperoleh melalui pengalaman langsung (Santosa, dkk., 2017). Hal ini dikatakan sesuai karena dalam penggunaan media siswa dapat terlibat secara langsung dalam melipat, mebuka, dan membaca materi yang terdapat pada media ini. Dengan memberikan pengalaman pada siswa maka mereka akan lebih paham akan materi yang dipelajari dan memahami materi lebih lama.

Media pop-up book pada topik perkembangbiakan tumbuhan dan hewan yang dikembangkan juga dapat memfasilitasi siswa dengan gaya belajar visual dan kinestetik. Siswa yang belajar dengan gaya visual akan belajar dengan cara melihat, memandangi, dan mengamati objek yang dipelajari sehingga 
lebih mudah memahami materi yang dipelajari. Sedangkan siswa yang belajar dengan gaya kinestetik lebih cenderung belajar menggunakan aktivitas fisik (Bire, dkk., 2014). Media pop-up book yang dikembangkan dapat memfasilitasi kedua gaya belajar tersebut. Siswa yang belajar dengan gaya visual dan kinestetik dapat mengamati setiap materi yang terdapat pada media dan dapat membuka halaman yang menarik pada media pop-up book sehingga akan memberikan pengalaman belajar yang bermakna pada siswa.

Beberapa hasil penelitian yang terdahulu seperti penelitian yang dilakukan oleh Khoiriyah \& Sari (2018) dalam penelitian ini dinyatakan bahwa tingkat kelayakan produk yang dilakukan oleh ahli materi dan media pembelajaran tergolong kategori valid dan layak untuk digunakan pada pembelajaran IPA. Hasil penelitian yang dilakukan oleh Ningtiyas, dkk (2019) yang menyatakan bahwa produk yang dikembangkan dinyatakan valid dengan tingkat kevalidan dari ahli media sebesar 96.59\% dan ahli materi sebesar $97.36 \%$ dan dalam penelitian ini juga dinyatakan bahwa dengan penggunaan media pop-up book siswa merasa senang dan lebih fokus terhadap materi yang dipelajari. Penelitian Safri, dkk., (2017) yang menyatakan bahwa media pop-up book yang dikembangkan sangat layak digunakan. Hal ini duperoleh dari hasil uji yang dilakukan oleh 5 validator dengan mendapatkan rata-rata presentase kelayakan sebesar 92,67\%. Penelitian Masturah, dkk., (2018) yang memperoleh hasil review ahli mata pelajaran sebesar 95,8\%, ahli desain pembelajaran mencapai 88\%, dan ahli media pembelajaran sebesar 98,5. Berdasarkan uji validitas media dinyatakan valid dengan kategori sangat baik. Berdasarkan beberapa hasil penelitian yang dilakukan sebelumnya, diyakini bahwa apabila media pop-up book pada topik perkembangbiakan tumbuhan dan hewan diimplementasikan di sekolah dasar maka dapat meningkatkan hasil belajar dan motivasi belajar siswa.

\section{Simpulan dan saran}

Berdasarkan hasil penelitian dan pembahasan dapat diambil kesimpulan bahwa media pop-up book pada topik perkembangbiakan tumbuhan dan hewan di kelas VI sekolah dasar memiliki klasifikasi sangat baik. Hasil analisis menunjukkan bahwa rata-rata skor validasi media yaitu 4.85. Hal ini menunjukkan bahwa media yang dikembangkan layak untuk digunakan. Media pop-up book yang dikembangkan dapat membantu siswa dalam proses pembelajaran, karena media pop-up book merupakan media yang memiliki visualisasi yang berbeda dengan media lainnya. Media pop-up book merupakan media yang memiliki unsur tiga dimensi yang apabila dibuka dapat memberikan kesan timbul. Dengan dikembangkannya media ini diharapkan dapat membantu siswa memahami materi khususnya pada topik perkembangbiakan tumbuhan dan hewan.

Berpijak pada hasil penelitian yang telah dilakukan adapun saran yang diberikan adalah agar siswa dapat menggunakan media pop-up book pada kegiatan pembelajaran khususnya pada topik perkembangbiakan tumbuhan dan hewan. Guru hendaknya mampu memfasilitasi siswa dalam proses pembelajaran, salah satunya dengan menggunakan media pop-up book. Apabila guru ingin mengembangkan media yang sejenis, dapat menggunakan penelitian ini sebagai referensi. Kepala sekolah hendaknya dapat memfasilitasi guru untuk mengikuti pelatihan atau workshop pengembangan media pembelajaran agar guru menjadi lebih kreatif dan mempu mencapai tujuan pembelajaran yang telah ditetapkan. Peneliti lain dapat menggunakan penelitian ini sebagai referensi dalam penelitian sejenis pada mata pelajaran atau topik yang berbeda.

\section{Daftar Rujukan}

Agung, Anak Agung Gede. 2014. Metodologi Penelitian Pendidikan. Yogyakarta: Deepublish.

Ambarsari, D. W., \& Hartono, B. 2017. "Pengembangan Media Pop Culture UP Rumah Adat Jawa untuk Pembelajaran Menyusun Teks Deskripsi pada Peserta Didik SMP Kelas VII". Jurnal Semantik, Volume 6, Nomor 2, (hlm. 1-10).

Anggraini, dkk. 2019. "Development of Pop-Up Book Integrated with Quranic Verses Learning Media on Temperature and Changes in Matter". Journal of Physics, (hlm. 1-9).

Baiduri., dkk, 2019. "Pengembangan Media Pembelajaran Pop-Up Book Berbasis Audio pada Materi Bangun Datar Segiempat di SMP". AKSIOMA: Jurnal Program Studi Pendidikan Matematika, Volume 8, Nomor 1, (hlm. 248-261).

Bire., dkk. 2014. "Pengaruh Gaya Belajar Visual, Auditorial, dan Kinestetik terhadap Prestasi Belajar Siswa". Jurnal Kependidikan, Volume 44, Nomor 2, (hlm. 168-174). 
Candiasa, I Made. 2011. Pengujian Instrumen Penelitian Disetrai Aplikasi ITEMAN dan BIGSTEPS. Singaraja: Undiksha Press.

Dewanti, Handaruni., dkk. 2018. "Pengembangan Media Pop-Up Book untuk Pembelajaran Lingkungan Tempat Tinggalku Kelas IV SDN 1 Pakunden Kabupaten Ponorogo". JKTP, Volume 1, Nomor 2 (hlm. 221-228)

Fadillah, Rachmadini Nur \& Ika Lestari. 2016. "Buku Pop-Up untuk Pembelajaran Bercerita Siswa Sekolah Dasar". Perspektif Ilmu Pendidikan, Volume 30, Nomor 1 (hlm. 21-26).

Ibda, Fatimah. 2015. "Perkembangan Kognitif: Teori Jean Piaget". Intelektualita, Volume 3, Nomor 1 (hlm. 27-38).

Inah, Ety Nur. 2015. "Peran Komunikasi dalam Interaksi Guru dan Siswa". Al-Ta'dib, Volume 8, Nomor 2 (hlm. 150-167).

Indriani. 2019. Hasil PISA Tunjukkan Perspektif Pendidikan Indonesia. Antarnews.

Karo-Karo, Isyan Rasyid \& Rohani. 2018. "Manfaat Media dalam Pembelajaran". AXIOM, Volume 1, Nomor 1 (hlm. 91-96).

Khoiriyah, Evi \& Eka Yuliana Sari. 2018. "Pengembangan Media Pembelajaran Pop-Up Book pada Mata Pelajaran IPA Kelas III SDN 3 Junjung Kecamatan Sumbergempol Kabupaten Tulungagung Tahun Ajaran 2017/2018". Jurnal Bidang Pendidikan Dasar (JBPD), Volume 2, Nomor 2 (hlm. 22-32).

Koyan, I Wayan. 2012. Statistik Teknik Analisis Data Kuantitatif. Singaraja: Universitas Pendidikan Ganesha.

Kumara, Amitya. 2004. "Model Pembelajaran "Active Learning" Mata Pelajaran Sains Tingkat SD Kota Yogyakarta Sebagai Upaya Peningkatan "Life Skills". Jurnal Psikologi, Nomor 2, (hlm. 63-91).

Kusnandi. 2017. "Model Inovasi Pendidikan dengan Strategi Implimentasi Konsep "Dare to be Different". Journal Wahana Pendidikan, Volume 4, Nomor 1 (hlm. 132-144).

Lubis, Rahmat Rifai. 2018. "Identifikasi Perilaku dan Karakteristik Awal Peserta Didik (Konsep dan Pola Penerapan Dalam Desain Instruksional)". Jurnal Hikmah, Volume 15, Nomor 1 (hlm. 28-34).

Maimunah. 2016. "Metode Penggunaan Media Pembelajaran". Jurnal Al-Afkar, Volume 5, Nomor 1 (hlm. 124).

Masturah, Elisa Diah., dkk. 2018. "Pengembangan Media Pembelajaran Pop-Up Book pada Mata Pelajaran IPA Kelas III Sekolah Dasar". Jurnal EDUTECH Universitas Pendidikan Ganesha, Volume 6, Nomor 2 (hlm. 212-221).

Monika, Icha. 2014. "Uji Aktivitas Ekstrak Kencur terhadap Pengendalian Pertumbuhan Fusarium oxysporum dan Implementasinya dalam Pembuatan Flipbook". Jurnal Pendidikan Dan Pembelajaran Khatulistiwa, Volume 3, Nomor 2 (hlm. 1-14).

Muhali. 2019. Pembelajaran Inovatif Abad Ke-21. Jurnal Penelitian Dan Pengkajian Ilmu Pendidikan: ESaintika, Volume 3, Nomor 2 (hlm. 25-50).

Mustika, Rieka. 2015. "Media Pembelajaran Sistem Audio untuk Pemberdayaan Pendidikan di Komunitas Masyarakat". Jurnal Masyarakat Telematika Dan Informasi, Volume 6, Nomor 1 (hlm. 57-68).

Ningtiyas, dkk. 2019. "Pengembangan Media Pop-Up Book untuk Mata Pelajaran IPA BAB Siklus Air dan Peristiwa Alam sebagai Penguatan Kognitif Siswa". Jurnal Kajian Teknologi Pendidikan, Volume 2, Nomor 2 (hlm. 115-120).

Oktaviarini, Nourma. 2017. "Pengembangan Media Pembelajaran Pop-Up Book Tema Lingkungan dan Alam Sekitar untuk Siswa Kelas IV SD di Kabupaten Blitar". Jurnal Pena SD, Volume 03, Nomor 01.

Rizal, Daviq. 2018. "Pendampingan Peningkatan Mutu Madrasah melalui Pembelajaran Aktif dan Manajemen Sekolah". Dimas: Jurnal Pemikiran Agama Untuk Pemberdayaan, Volume 18, Nomor 2, (hlm. 327-344).

Safri, Meilia., dkk. 2017. "Pengembangan Media Belajar Pop-Up Book pada Materi Minyak Bumi. Jurnal Pendidikan Sains Indonesia", Volume 05, Nomor 01, (hlm. 107-113).

Santosa, Alif Satria Egar., dkk. 2017. "Pengembangan E-Modul Berbasis Model Pembelajaran Problem 
Based Learning pada Mata Pelajaran Administrasi Jaringan Kelas XII Teknik Komputer Dan Jaringan di SMK TI Bali Global Singaraja". Kumpulan Artikel Mahasiswa Pendidikan Teknik Informatika (KARMAPATI), Volume 6, Nomor 1, (hlm 62-72).

Sholikhah, Aimatus. 2017. "Pengembangan Media Pop Up Book untuk Meningkatkan Kemampuan Menulis Kreatif pada Mata Pelajaran Bahasa Indonesia Materi Menulis Karangan Kelas V SDN Rowoharjo Tahun Ajaran 2016/2017". Simki-Pedagogia, Volume 01, Nomor 08 (hlm. 1-8).

Tegeh, I Made \& I Nyoman Jampel. 2017. Metode Penelitian Pengembangan. Singaraja: Universitas Pendidikan Ganesha.

Wati, Elis Trisdiana \& Ulhaq Zuhdi. 2017. "Pengaruh Media Pop-Up Book terhadap Hasil Belajar Siswa Tema Ekosistem Kelas V SDN Karangpilang 1 Surabaya". JPGSD, Volume 05, Nomor 03 (hlm. 913923). 